\title{
Biomonitoring of chlorpyrifos exposure and health risk assessment among applicators on rice farms in Ghana
}

Albert Atabila a, ${ }^{\mathrm{a}}$, Ross Sadler ${ }^{\mathrm{a}}$, Dung Tri Phung ${ }^{\mathrm{a}}$, Jonathan N. Hogarh ${ }^{\mathrm{b}}$, Stewart Carswell ${ }^{\mathrm{c}}$, Scott Turner ${ }^{\mathrm{c}}$, Renu Patel ${ }^{\mathrm{c}}$, Des Connell ${ }^{\mathrm{a}}$, and Cordia $\mathrm{Chu}^{\mathrm{a}}$

${ }^{a}$ Centre for Environment and Population Health, Griffith School of Environment, Griffith University, 170 Kessels Road, Nathan, QLD 4111, Australia.

${ }^{b}$ Department of Environmental Science, College of Science, Kwame Nkrumah University of Science and Technology, Kumasi, Ghana.

${ }^{c}$ Queensland Health Forensic and Scientific Services, 39 Kessels Road, Coopers Plains, QLD 4108, Australia.

* Corresponding author's contact details-

Email: albert.atabila@griffithuni.edu.au

Telephone: +61737354124

Fax: +61737355318

\section{Acknowledgements}

This study was supported with funding from Griffith University (Griffith University International Postgraduate Research Scholarship, Griffith University Postgraduate Research Scholarship), Griffith School of Environment ( $\mathrm{PhD}$ fieldwork fund), Griffith School of Engineering, the Organic Chemistry Department of Queensland Health Forensic and Scientific Services and Dr. Ross Sadler. Special thanks go to the rice farmers of Asutsuare and Akuse (Ghana), as well as the staff of Kpong Irrigation Scheme (Asutsuare, Ghana), particularly Albert F. Swatson, Raphael Edifor, Samuel Kwakye and Moses Kodjotse, for their tremendous support during the field work. The authors are also grateful to Mrs. Benedicta Adewuti, Martin Amega-Yevu and Ishmael Sumaila Narteh of Osukoku Health Centre (Asutsuare) for their assistance during the fieldwork. 


\begin{abstract}
Chlorpyrifos is a neurotoxic insecticide that is widely used in the agricultural sector of Ghana. The main objective of this study was to evaluate the levels of chlorpyrifos exposure and health risk among applicators $(\mathrm{n}=21)$ on irrigated rice farms in Ghana, based on a typical application event. Pre- and post-application urine samples (24-hour) were collected from the applicators and analysed for 3, 5, 6-trichloro-2-pyridinol (TCP), using LC-MS/MS. The levels of chlorpyrifos absorbed dose with the applicators were estimated from the urinary TCP levels. Prior to application, the median absorbed dose of chlorpyrifos (background exposure) with the applicators was $0.2 \mu \mathrm{g} / \mathrm{kg} /$ day (range, 0.05 to $2 \mu \mathrm{g} / \mathrm{kg} /$ day). Following application, the median absorbed dose of chlorpyrifos (application exposure) increased 30-fold to $6 \mu \mathrm{g} / \mathrm{kg} /$ day (range, 0.7 to $74 \mu \mathrm{g} / \mathrm{kg} /$ day). The mean elimination half-life $\left(\mathrm{t}_{1 / 2}\right)$ of chlorpyrifos was calculated to be 50 hours. Hazard Quotient (HQ) values (HQ > 1) obtained with the chronic (10 $\mu \mathrm{g} / \mathrm{kg} / \mathrm{day})$ and acute $(100 \mu \mathrm{g} / \mathrm{kg} /$ day $)$ guideline values of the WHO suggested no risk of chronic or acute health effects, respectively, among both the median- and 5\%-highly exposed groups. However, HQ values $(\mathrm{HQ}>1)$ obtained with the chronic $(0.3 \mu \mathrm{g} / \mathrm{kg} / \mathrm{day})$ and acute $(5 \mu \mathrm{g} / \mathrm{kg} /$ day $)$ guideline values of the USEPA suggested risk of chronic and acute health effects, respectively, among both the median- and 5\%-highly exposed groups. The quantity of chlorpyrifos formulation applied, spraying duration and the number of spray tanks applied significantly correlated with the absorbed dose levels of chlorpyrifos from application exposure; and therefore, suggest means to reduce exposure and consequent health risk among the applicators.
\end{abstract}

\title{
Keywords:
}

biomonitoring; biomarker; chlorpyrifos; pesticide; exposure assessment; risk assessment 


\subsection{Introduction}

Chlorpyrifos [O, O-diethyl O-(3, 5, 6-trichloro-2-pyridyl) phosphorothioate] is a broadspectrum organophosphate insecticide that is commonly used worldwide for the control of agricultural, ornamental, public health and structural pests (Eaton et al. 2008; Grube et al. 2011; John and Shaike 2015). Chlorpyrifos is neurotoxic with its main mechanism of toxicity expressed through inhibition of the enzyme acetylcholinesterase (AChE- EC 3.1.1.7), which is responsible for the breakdown of the neurotransmitter, acetylcholine (Das et al. 2006; Garabrant et al. 2009). This action leads to overstimulation of muscarinic and nicotinic receptors leading to acute adverse effects, such as tremor, paralysis, confusion, convulsion, coma, and gastro-intestinal distress (Colombo et al. 2005; Costa 2006; Yang and Deng 2007). In addition, chronic health effects, such as developmental and neurobehavioral anomalies, have been associated with chlorpyrifos (Rauh et al. 2012; Whyatt et al. 2004).

Agriculture contributes over 30\% to Ghana's Gross Domestic Product (GDP), providing livelihood for over 50\% of the labour force (Kolavalli et al. 2012). The agricultural sector in Ghana relies substantially on the use of pesticides (Fosu-Mensah et al. 2016; Gerken et al. 2001), with chlorpyrifos being one of the most commonly used (Amoah et al. 2006). But unsafe pesticide handling practices (Mattah et al. 2015; Okoffo et al. 2016) put applicators at risk of excessive exposure and adverse health effects. However, evaluation of the levels of chlorpyrifos exposure among applicators in Ghana are limited, despite the potential health risks.

TCP (3, 5, 6-trichloro-2-pyridinol) is the primary metabolite of chlorpyrifos (Nolan et al. 1984)

(Figure 1). In humans exposed to chlorpyrifos, TCP is excreted mainly via the urinary pathway. 
Urinary TCP has therefore been widely used as a biomarker to evaluate exposure to chlorpyrifos (Alexander et al. 2006; Baker et al. 2005; Farahat et al. 2011; Phung et al. 2012b). A major advantage of the use of TCP is that, it incorporates exposure from all routes and therefore gives an overall measure of exposure (Albertini et al. 2006; Barr and Angerer 2006). However, a disadvantage of this approach is that, there are multiple sources of TCP in the environment, such as from water and food (background exposure), in addition to occupational sources. Therefore, measured TCP levels in occupationally exposed individuals may incorporates exposure from non-occupational pathways, leading to over-estimation of occupational exposure (Barr and Angerer 2006; Eaton et al. 2008; Lu et al. 2005). Nonetheless, this challenge can be addressed by correcting occupational TCP levels for background TCP levels.

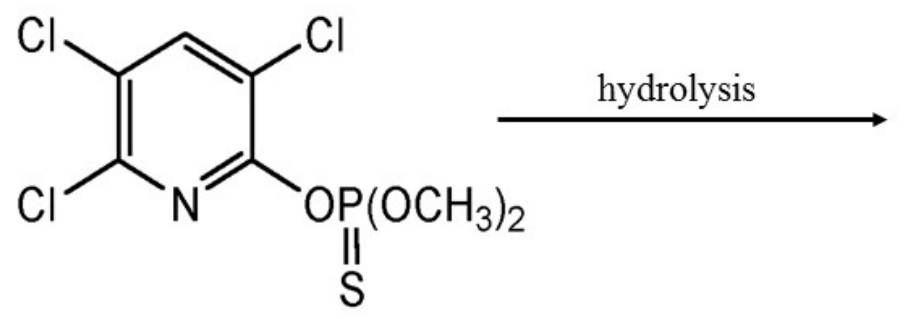<smiles>Oc1nc(Cl)c(Cl)cc1Cl</smiles>

chlorpyrifos 3, 5, 6-trichloro-2-pyridinol (TCP)

Fig. 1 Chemical structure of chlorpyrifos and its hydrolysed metabolite 3, 5, 6-trichloro-2pyridinol 
The main objective of this study was to evaluate chlorpyrifos exposure and consequent health risk, based on urinary TCP, among applicators who frequently use the insecticide on irrigated rice farms in Ghana.

\subsection{Methods}

\subsection{Study Area and Participants}

The study was conducted from $5^{\text {th }}$ to $31^{\text {st }}$ December 2015 , with a group of applicators who grow rice with irrigation in the southern part of Ghana, under small scale $(<2 \mathrm{ha})$ farming conditions. All of the applicators of the study sprayed rice crops with chlorpyrifos (Dursban 480g/L Emulsifiable Concentrate), using hand-pressurized knapsack spraying devices that were carried on the back. In the process of spraying, the applicators positioned the lance of the spray device at their front above the crops while spraying and walking forward through the sprayed area and spray cloud.

Information about the study and request for particitrousers were circulated among the applicators through local Agricultural Extension Officers. Applicators $(n=21)$ who expressed an interest in participation, ready to satisfy the study requirements (Section 2.3) and had their pesticide application schedule fall within the sampling period were selected. Ethical approval for the study was obtained from Ghana Health Service Ethical Review Committee (GHS-ERC: 10/07/15) and Griffith University Human Ethics Committee (ENV/24/15/HREC).

\subsection{Urine Sampling Procedure}

This exposure assessment study was based on a single pesticide application event for each applicator on separate occasions. Information, such as Personal Protective Equipment (PPE) 
usage, type of clothing worn, application duration, quantity of insecticide applied, number of spray tanks, crop height, farm size, as well as incidences of spills and leakages were observed and recorded during the spray event. Also, information on age, educational level, exposure frequency and exposure duration (work lifetime) of the applicators were collected using a questionnaire.

Prior to sampling, the applicators were given one-day training on self-sampling procedures for taking 24-hour urine samples. In the evening preceding the sampling days, each applicator was given a set of sampling items, which comprised an ice chest ( $8 \mathrm{~L})$, ice packs, and a plastic jar (2 L) to keep the urine samples at $4^{\circ} \mathrm{C}$. Each applicator was required to submit six 24-hour urine samples, which included one sample before the application day (background sample), one sample during the application day (from start of application to the same time of the subsequent day), and four samples at 24- hour intervals after the end of the application day (post-application) sampling period. The applicators were requested not to apply chlorpyrifos for at least one week prior to the first sampling day and another week after the application day.

Three aliquots were prepared from each sample and stored in HDPE bottles $(60 \mathrm{~mL})$. One set of the aliquot samples was analysed for creatinine at Patholab Solutions in Accra. The second set was shipped with dry ice $(20 \mathrm{~kg})$ by air to Queensland Health Forensics and Scientific Services (QHFSS) in Brisbane for TCP analysis. The third set of the aliquot samples was kept as a reserve. All the samples were stored at $-25^{\circ} \mathrm{C}$ until analysis. 


\subsection{Analysis of Urinary TCP}

Aliquots of urine $(1 \mathrm{~mL})$ were spiked with isotopically labelled TCP $\left({ }^{13} \mathrm{C}_{5}-\mathrm{TCP}\right.$, Toronto Research Chemicals, Toronto, Canada), adjusted to $\mathrm{pH}>12$ with $10 \mathrm{M} \mathrm{NaOH}$ and hydrolysed at $60^{\circ} \mathrm{C}$ for two hours. The samples were then adjusted to $\mathrm{pH}<3$ with $42.5 \% \mathrm{w} / \mathrm{w} \mathrm{H}_{3} \mathrm{PO}_{4}$ and $0.45 \mu \mathrm{m}$ filtered (13mm Phenex RC, Phenomenex, Torrance, USA). The prepared samples were analysed by Liquid Chromatography Tandem Mass Spectrometry (LC-MS/MS) in positive ESI mode on a Shimadzu Prominence UFLC (Kyoto, Japan) coupled to an Applied Biosystems API 4000 mass spectrometer (Framingham, USA) using a Kinetex C18 column (50x2.1mm, 5 $\mu \mathrm{m}$, Phenomenex, Torrance, USA) and a $1 \%$ to $95 \%$ methanol gradient with $0.1 \%$ acetic acid.

Quality control of the analysis phase consisted of duplicate samples, spiked samples, conjugate spiked samples, blank samples, spiked blank samples, and conjugate spiked blank samples run every $20^{\text {th }}$ samples. Synthetic urine, as per Method 6301.02 of the Centre for Disease Control and Prevention (CDC), was used as the blank matrix. Conjugate spiked samples were spiked with TCP Glucuronide (Carbosynth, Compton, UK) to monitor hydrolysis performance. TCP for spiked samples and standards was sourced from Dr. Ehrenstorfer GmbH (Augsburg, Germany). QHFSS is accredited by the National Association of Testing Authorities (NATA, Australia) and complies with ISO 17025 standards for chemical testing.

\subsection{Analysis of Urinary Creatinine}

Urinary creatinine concentrations were determined and used to normalize the urinary TCP concentrations, to compensate for urine volume variation (Barr et al. 2005; Cocker et al. 2011). Determination of creatinine was based on the kinetic Jaffe reaction colorimetric method 
(Mohabbati-Kalejahi et al. 2012). The analysis was carried out using a Mindray BS-120 automated analyzer (Shenzhen Mindray Bio-Medical Electronics Co., Ltd). Duplicate of every $10^{\text {th }}$ sample was analysed and the average duplicate analysis comparison was $2.5 \%$.

\subsection{Estimation of Chlorpyrifos Absorbed Dose Levels}

\subsubsection{Absorbed Daily Dose of Chlorpyrifos from Application Exposure $\left(A D D_{A}\right)$}

Using the post-application urinary TCP levels (Table 6.7) the levels of Absorbed Daily Dose of chlorpyrifos from application exposure $\left(\mathrm{ADD}_{\mathrm{A}}\right)$ (acute application exposure) were calculated from the equation below (Fenske et al. 2012; Phung et al. 2012a):

$$
\mathrm{ADD}_{\mathrm{A}}(\mu \mathrm{g} / \mathrm{kg} / \text { day })=\left[\mathrm{C} \times \mathrm{Cn} \times \mathrm{CF} \times\left(\mathrm{MW}_{\mathrm{CPF}} / \mathrm{MW}_{\mathrm{TCP}}\right)\right] / \mathrm{BW} \quad \text { Equation } 1
$$

where, $\mathrm{C}$ is the concentration of TCP excreted per day ( $\mu \mathrm{g} / \mathrm{g}$ creatinine); $\mathrm{Cn}$, expected mass of creatinine excreted per day(g/day); CF, correction factor of 100/70 for urinary TCP (about $70 \%$ of chlorpyrifos is excreted as TCP in urine ) (Nolan et al. 1984); $\mathrm{MW}_{\mathrm{CPF}}$, the molecular weight of chlorpyrifos $(350.6 \mathrm{~g} / \mathrm{mol})$; $\mathrm{MW}_{\text {TCP }}$ the molecular weight of TCP $(198.5 \mathrm{~g} / \mathrm{mol})$; and BW, the body weight of each applicator $(\mathrm{kg})$.

\subsubsection{Lifetime Average Daily Dose of Chlorpyrifos from Application Exposure $\left(L A D D_{A}\right)$}

The levels of Lifetime Average Daily Dose of Chlorpyrifos from application Exposure $\left(\mathrm{LADD}_{\mathrm{A}}\right)$ (chronic application exposure) were estimated from the $\mathrm{ADD}_{\mathrm{A}}$ levels using 
additional data, to calculate long term occupational exposure. The estimation was done using the equation below (Health Canada, 2014; Phung et al. 2012a; USEPA, 2007):

$$
\mathrm{LADD}_{\mathrm{A}}=\left(\mathrm{ADD}_{\mathrm{A}} \times \mathrm{EF} \times \mathrm{ED}\right) / \mathrm{AT} \quad \text { Equation } 2
$$

where, $\mathrm{ADD}_{\mathrm{A}}(\mu \mathrm{g} / \mathrm{kg} / \mathrm{day})$ is the Absorbed Daily Dose of chlorpyrifos from application exposure; EF, the Exposure Frequency (number of applications in days per year); ED, the Exposure Duration (work lifetime years); and AT, the Averaging Time [(life expectancy at birth in years - application start age in years) x 365 days/ year]. The life expectancy at birth for men in Ghana is 62 years (WHO, 2015).

\subsubsection{Lifetime Average Daily Dose of Chlorpyrifos from Background Exposure $\left(L A D D_{B}\right)$}

The levels of Lifetime Average Daily Dose of chlorpyrifos from background exposure $\left(\mathrm{LADD}_{\mathrm{B}}\right)$ were estimated from the background urinary TCP levels of the applicators. Unlike the $\mathrm{LADD}_{\mathrm{A}}$ levels, the $\mathrm{LADD}_{\mathrm{B}}$ levels were not estimated from acute exposure (ADD). Rather, $\mathrm{LADD}_{\mathrm{B}}$ levels were based on direct TCP measurements from daily background exposure. Therefore, it was unnecessary to apply estimation factors such as Exposure Frequency (EF), Exposure Duration (ED) and Averaging Time (AT). Thus, the $\mathrm{LADD}_{\mathrm{B}}$ levels were estimated using Equation 1. 


\subsection{Determination of the Relationships between Absorbed Daily Dose of Chlorpyrifos from Application Exposure $\left(A D D_{A}\right)$ and Field Factors}

An evaluation was carried out to assess the relationships between $\mathrm{ADD}_{\mathrm{A}}$ (as a dependant variable) and field factors (as independent variables) which were observed and recorded during the application events. The $\mathrm{ADD}_{\mathrm{A}}$ data of the applicators were not normally distributed as judged by Shapiro-Wilk test $(\mathrm{p}<0.001)$. Consequently, the non-parametric Spearman $\rho$ test was applied to evaluate correlations between $\mathrm{ADD}_{\mathrm{A}}$ and continuous independent variables (application duration, insecticide formulation quantity, number of spray tanks, farm size, and crop height). For categorical independent variables (type of shirt, incidence of leaky tank, and incidence of insecticide spillage), the Mann-Whitney $U$ test was used to compare the differences in $\mathrm{ADD}_{\mathrm{A}}$ levels between groups. The SPSS computer program (Version 20) was used for the analysis.

\subsection{Health Risk Characterization}

The ADD and LADD data were ranked from the lowest to the highest, after which the Cumulative Probabilities (CPs) were calculated using the equation below:

$$
\mathrm{CP}(\%)=(\mathrm{i} / \mathrm{n}+1) \times 100
$$

Equation 3

where, $\mathrm{CP}$ is cumulative probability $(\%), \mathrm{i}$, the $\mathrm{i}^{\text {th }}$ point and $\mathrm{n}$, the total number of data points.

The Cumulative Probability Distribution (CPD) plots for ADD and LADD were constructed using the $\mathrm{CP}$ values. The risk of adverse health effect was characterized by dividing the 
exposure dose at the $50^{\text {th }}\left(\mathrm{HQ}_{50}\right)$ and $95^{\text {th }}\left(\mathrm{HQ}_{95}\right)$ percentiles by the guideline values set by WHO and USEPA for chlorpyrifos. These two agencies are the major ones in the field of health risk assessment, with the WHO being concerned with global issues and USEPA, with national issues. Countries without their own national guideline values generally rely on those set by these agencies for health risk assessment evaluations. According to the WHO, the acute and chronic guideline values of chlorpyrifos are $100 \mu \mathrm{g} / \mathrm{kg} /$ day and $10 \mu \mathrm{g} / \mathrm{kg} / \mathrm{day}$, respectively (WHO 2009). However much lower guideline values have been set by the USEPA. The acute guideline value is set at $5 \mu \mathrm{g} / \mathrm{kg} / \mathrm{day}$, while the chronic guideline value is set at $0.3 \mu \mathrm{g} / \mathrm{kg} / \mathrm{day}$ (Smegal 2000).

\subsection{Results}

\subsection{Personal Characteristics of the Applicators and Observed Field Factors During Application}

The personal characteristics of the applicators and the field factors recorded in this research are presented in Table 1. All the applicators were male aged between 23 to 53 years. Fifty eight percent of the applicators were educated up to Junior High School (JHS) level. The applicators had used insecticides for between 5 and 32 years. The exposure frequency and exposure duration (work life time) of the applicators ranged from 4 to 10 days per years and 25 to 45 years, respectively.Most the applicators wore long trousers (95\%) and about half (52\%) wore short sleeve shirts. Two of the applicators (9\%) used safety glasses during the application while the rest (91\%) did not use any PPE. Incidences of pesticide leakage and spillage were observed among $52 \%$ and $81 \%$ of the applicators, respectively. The mean size of the farms treated was 0.6 ha and crop height was $49 \mathrm{~cm}$. With the quantity of chlorpyrifos (Emulsifiable Concentrate - EC) applied, the mean was $224 \mathrm{~mL}$ and duration of application was $82 \mathrm{~min}$. 
Table 1: Personal Characteristics of Applicators and Observed Field Factors During Spraying of Rice Crops with Chlorpyrifos in Ghana $(n=21)$

\begin{tabular}{|c|c|c|}
\hline Variable & Category/Statistic & Quantity \\
\hline Educational level (\%) & $\begin{array}{c}\text { Up to Junior High School } \\
\text { (9 years of formal education) } \\
\text { Above Junior High School } \\
\text { (more than } 9 \text { years of formal education) }\end{array}$ & $\begin{array}{l}58 \\
42\end{array}$ \\
\hline Age (years) & $\begin{array}{l}\text { Range } \\
\text { Mean }\end{array}$ & $\begin{array}{c}23 \text { to } 53 \\
40\end{array}$ \\
\hline $\begin{array}{l}\text { Years of insecticide } \\
\text { application }\end{array}$ & $\begin{array}{l}\text { Range } \\
\text { Mean }\end{array}$ & $\begin{array}{c}5 \text { to } 32 \\
16\end{array}$ \\
\hline $\begin{array}{l}\text { Exposure frequency } \\
\text { (days per year) }\end{array}$ & $\begin{array}{l}\text { Range } \\
\text { Mean }\end{array}$ & $\begin{array}{c}4 \text { to } 10 \\
6 \\
\end{array}$ \\
\hline $\begin{array}{l}\text { Exposure duration } \\
\text { (work lifetime) (years) }\end{array}$ & $\begin{array}{l}\text { Range } \\
\text { Mean }\end{array}$ & $\begin{array}{c}25 \text { to } 45 \\
35\end{array}$ \\
\hline Type of trousers (\%) & $\begin{array}{l}\text { Long } \\
\text { Short }\end{array}$ & $\begin{array}{c}95 \\
5\end{array}$ \\
\hline Type of shirt (\%) & $\begin{array}{l}\text { Long } \\
\text { Short }\end{array}$ & $\begin{array}{l}52 \\
48\end{array}$ \\
\hline Use of PPE (\%) & $\begin{array}{l}\text { Yes } \\
\text { No }\end{array}$ & $\begin{array}{c}9 \\
91 \\
\end{array}$ \\
\hline Leaky tank (\%) & $\begin{array}{l}\text { Yes } \\
\text { No }\end{array}$ & $\begin{array}{l}52 \\
48 \\
\end{array}$ \\
\hline Spillage (\%) & $\begin{array}{l}\text { Yes } \\
\text { No }\end{array}$ & $\begin{array}{l}81 \\
19 \\
\end{array}$ \\
\hline Farm size (ha) & $\begin{array}{l}\text { Range } \\
\text { Mean }\end{array}$ & $\begin{array}{c}0.24 \text { to } 1 \\
0.61\end{array}$ \\
\hline Crop height $(\mathrm{cm})$ & $\begin{array}{l}\text { Range } \\
\text { Mean }\end{array}$ & $\begin{array}{c}13 \text { to } 100 \\
49 \\
\end{array}$ \\
\hline $\begin{array}{l}\text { Insecticide quantity } \\
(\mathrm{mL})\end{array}$ & $\begin{array}{l}\text { Range } \\
\text { Mean }\end{array}$ & $\begin{array}{c}88 \text { to } 600 \\
224 \\
\end{array}$ \\
\hline $\begin{array}{l}\text { Spraying duration } \\
\text { (min) }\end{array}$ & $\begin{array}{l}\text { Range } \\
\text { Mean }\end{array}$ & $\begin{array}{c}25 \text { to } 224 \\
82\end{array}$ \\
\hline
\end{tabular}




\subsection{Urinary TCP Levels of the Applicators}

The creatinine-normalized background (baseline) and post-application urinary TCP levels found with the applicators in the study are presented in Table 2. Out of a total of 126 urine samples obtained from the applicators, 14 (12 background samples and 2 post-application samples) had TCP levels below the Limit of Quantification (LOQ) $(5 \mu \mathrm{g} / \mathrm{L})$. Generally, measurements below this limit does not necessarily imply that there is zero exposure (Solomon et al. 2005). Thus, these samples were assigned a value of half the LOQ (Beal 2001).

Two applicators (numbers 2 and 9, marked with an asterisk symbol in Table 2) were observed to apply significant quantities (200 and $250 \mathrm{~mL}$ ) of chlorpyrifos (Dursban, 480g/L EC) with similar application practices to the other applicators. However, they appeared not be exposed based on their post-application TCP levels, which were less than their respective background levels. The chlorpyrifos formulation used by these applicators was therefore suspected to be adulterated or another product substituted. This is common in farming communities in Ghana (MoFA, 2011). Also, applicator number 18 had background TCP level of $124 \mu \mathrm{g}$ TCP/g creatinine, which was about 36 times higher than the mean background TCP of the rest of the applicators. It is suggested that the high background TCP found with applicator number 18 might be due to non-reported use of chlorpyrifos product the week prior to the urine sampling, contrary to the requirements of the study. As a result of these considerations, the post-application TCP from the three applicators (marked with asterisk symbol in Table 2) were excluded from the statistical analysis of the study. The exclusion criteria applied in this study were similar to those used in previous studies (Ross et al. 2008; Scher et al. 2008). 
The background urinary TCP levels ranged from 1 to $36 \mu \mathrm{g}$ TCP/g creatinine with a median of 3 $\mu \mathrm{g} \mathrm{TCP} / \mathrm{g}$ creatinine and a mean of $6 \mu \mathrm{g} \mathrm{TCP} / \mathrm{g}$ creatinine. With post-application urinary $\mathrm{TCP}$, the levels found ranged from 11 to $1,550 \mu \mathrm{g} \mathrm{TCP} / \mathrm{g}$ creatinine, with a median of $105 \mu \mathrm{g} \mathrm{TCP} / \mathrm{g}$ creatinine and a mean of $353 \mu \mathrm{g} \mathrm{TCP} / \mathrm{g}$ creatinine.

Table 2: Urinary TCP ( $\mu \mathrm{g} / \mathrm{g}$ creatinine) Levels of Applicators on Rice Farms in Ghana $(\mathrm{n}=21)$.

\begin{tabular}{|c|c|c|c|c|c|c|c|}
\hline \multirow{2}{*}{ Applicator } & \multirow{2}{*}{$\begin{array}{c}\text { Background } \\
\text { TCP }\end{array}$} & \multicolumn{6}{|c|}{$\begin{array}{l}\text { Post-application Urinary TCP } \\
\text { (corrected for background TCP) }\end{array}$} \\
\hline & & Day 0 & Day 1 & Day 2 & Day 3 & Day 4 & Total \\
\hline 01 & $4^{\#}$ & 41 & 95 & 80 & 65 & 54 & 335 \\
\hline $02 *$ & 7 & -2 & 3 & 0 & -1 & 2 & 1 \\
\hline 03 & $2^{\#}$ & 38 & 37 & 21 & 14 & 3 & 114 \\
\hline 04 & 5 & 3 & 2 & 1 & 2 & 3 & 12 \\
\hline 05 & $3^{\#}$ & 3 & 3 & $1^{\#}$ & 1 & 3 & 11 \\
\hline 06 & $2^{\#}$ & 9 & 9 & 10 & 12 & 4 & 45 \\
\hline 07 & $8^{\#}$ & 20 & 129 & 40 & 36 & 26 & 250 \\
\hline 08 & $4^{\#}$ & 9 & 13 & 6 & 7 & 3 & 38 \\
\hline $09^{*}$ & $2^{\#}$ & 2 & 3 & $0^{\#}$ & $0^{\#}$ & $-3^{\#}$ & 1 \\
\hline 10 & $2^{\#}$ & 60 & 70 & 67 & 46 & 34 & 276 \\
\hline 11 & 9 & 423 & 470 & 301 & 227 & 125 & 1550 \\
\hline 12 & 11 & 99 & 107 & 36 & 23 & 45 & 311 \\
\hline 13 & $3^{\#}$ & 34 & 13 & 20 & 18 & 6 & 91 \\
\hline 14 & $4^{\#}$ & 194 & 193 & 174 & 94 & 116 & 771 \\
\hline 15 & $3^{\#}$ & 24 & 31 & 26 & 10 & 4 & 96 \\
\hline 16 & $3^{\#}$ & 11 & 31 & 30 & 23 & 20 & 116 \\
\hline 17 & $1^{\#}$ & 5 & 13 & 9 & 11 & 5 & 43 \\
\hline $18^{*}$ & 124 & 136 & 86 & -25 & -45 & 111 & 264 \\
\hline 19 & 3 & 5 & 10 & 9 & 6 & $2^{\#}$ & 32 \\
\hline 20 & 4 & 139 & 310 & 173 & 230 & 122 & 973 \\
\hline 21 & 36 & 372 & 407 & 284 & 153 & 142 & 1360 \\
\hline Minimum & 1 & 3 & 2 & 1 & 1 & 2 & 11 \\
\hline Median & 3 & 29 & 34 & 28 & 20 & 5 & 105 \\
\hline Mean & 6 & 83 & 108 & 72 & 54 & 40 & 350 \\
\hline SD & 8 & 126 & 145 & 96 & 74 & 53 & 480 \\
\hline SEM & 2 & 30 & 34 & 23 & 18 & 13 & 110 \\
\hline Maximum & 36 & 420 & 470 & 301 & 230 & 142 & 1550 \\
\hline
\end{tabular}

*The results from these applicators were excluded from further analysis for reasons outlined in Section 3.3 
\# The original TCP level measured in $\mu \mathrm{g} / \mathrm{L}$ urine is less than the LOD $(5 \mu \mathrm{g} / \mathrm{L})$ but was assigned a value of $2.5 \mu \mathrm{g} / \mathrm{L}$ as explained in Section 3.2.

\subsection{Elimination Half-life of Chlorpyrifos Found with the Applicators}

The time-concentration profile of Absorbed Daily Dose $\left(\mathrm{ADD}_{\mathrm{A}}\right)$ of chlorpyrifos estimated from the TCP levels of the applicators, following a spray event is shown in Figures 2 and 3. The mean $\mathrm{ADD}_{\mathrm{A}}$ of chlorpyrifos peaked at $5.5 \mu \mathrm{g} / \mathrm{kg} /$ day on day one after which the level rapidly declined on the subsequent days. Similar excretion patterns have been reported in previous studies (Mandel et al. 2005; Meuling et al. 2005; Phung et al. 2012b). The decline of chlorpyrifos with time was found to follow first-order kinetics with the following equation from Figure 3:

$$
\ln \mathrm{ADD}_{\mathrm{A}}=-0.327 \text { Time }+2 \quad\left(\mathrm{R}^{2}=0.99\right) \quad \text { Equation } 4
$$

The first-order elimination half-life $\left(\mathrm{t}_{1 / 2}\right)$ of chlorpyrifos with the applicators was determined by using the elimination rate constant $(k, 0.327)$ from Equation 4 , and then applying the equation, $\mathrm{t}_{1 / 2}$ $=0.693 / k$ (Toutain and Bousquet-Melou 2004). Thus, $\mathrm{t}_{1 / 2}=2.1$ days (50 hours). 


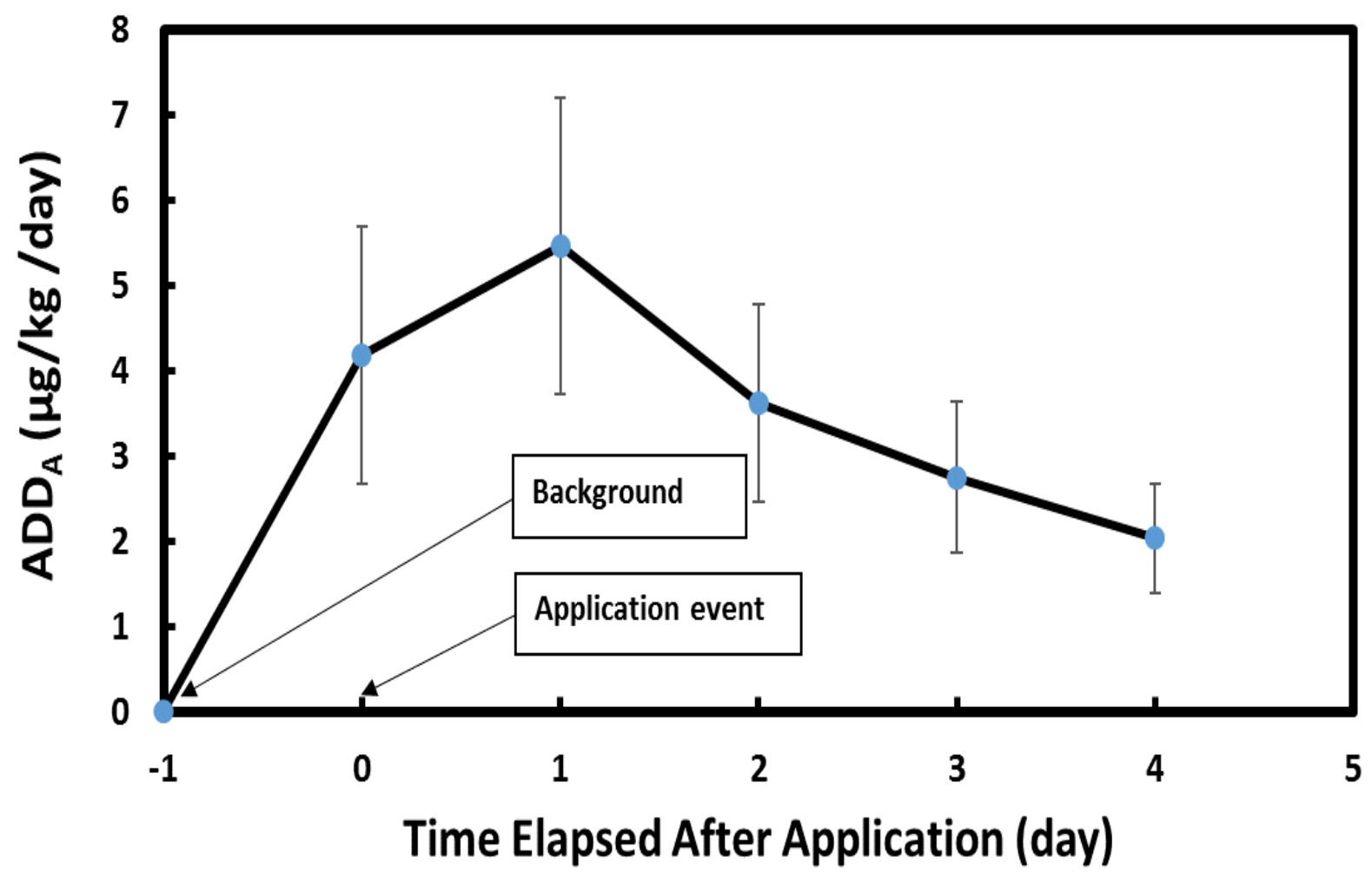

Fig. 2 Time-Absorbed Dose (Mean $\mathrm{ADD}_{\mathrm{A}} \pm$ S.E.M) Profile of Chlorpyrifos (Corrected for Background) Found with Applicators on Rice Farms in Ghana After One Application ( $\mathrm{n}=18)$

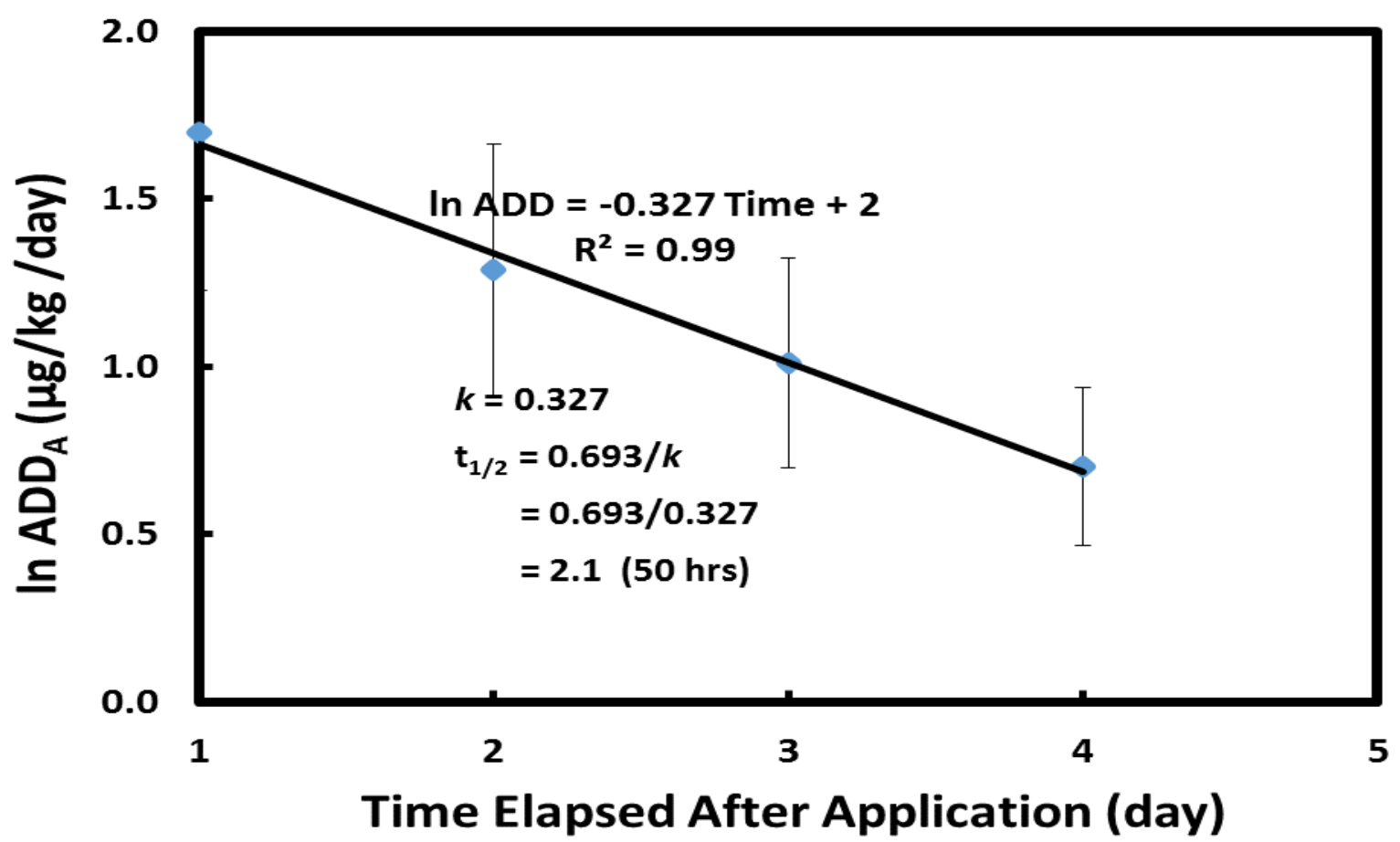

Fig. 3 Semi-Logarithmic Time-Absorbed Dose (Mean $\mathrm{ADD}_{\mathrm{A}} \pm$ S.E.M) Profile of Chlorpyrifos (Corrected for Background) Found with Applicators on Rice Farms in Ghana After One Application $(\mathrm{n}=18)$ 


\subsection{Absorbed Doses of Chlorpyrifos found with the Applicators}

The Lifetime Average Daily Dose of Chlorpyrifos from Background Exposure (LADD $)$, Lifetime Absorbed Daily Dose of Chlorpyrifos from application exposure (LADD $A$ ) and Absorbed Daily Dose of Chlorpyrifos from application exposure $\left(\mathrm{ADD}_{\mathrm{A}}\right)$ found with the Applicators are shown in Table 3. The $\mathrm{LADD}_{\mathrm{B}}$ levels ranged from 0.05 to $2 \mu \mathrm{g} / \mathrm{kg} / \mathrm{day}$, with a median of 0.2 $\mu \mathrm{g} / \mathrm{kg} / \mathrm{day}$ and mean of $0.3 \mu \mathrm{g} / \mathrm{kg} /$ day. With $\mathrm{LADD}_{\mathrm{A}}$, the levles ranged from 0.01 to $1 \mu \mathrm{g} / \mathrm{kg} / \mathrm{day}$, with a median of $0.1 \mu \mathrm{g} / \mathrm{kg} /$ day and a mean of $0.3 \mu \mathrm{g} / \mathrm{kg} /$ day. The $\mathrm{ADD}_{\mathrm{A}}$ levels ranged from 0.7 to $74 \mu \mathrm{g} / \mathrm{kg} / \mathrm{day}$, with a median of $6 \mu \mathrm{g} / \mathrm{kg} /$ day and a mean of $19 \mu \mathrm{g} / \mathrm{kg} / \mathrm{day}$. 
Table 3: Absorbed Doses ( $\mu \mathrm{g} / \mathrm{kg} /$ day) of Chlorpyrifos with Applicators on Rice Farms in Ghana $(\mathrm{n}=18)$.

\begin{tabular}{|l|c|c|c|}
\hline \multicolumn{1}{|c|}{ Statistic } & LADD $_{\mathbf{B}}$ & LADD $_{\mathbf{A}}$ & ADD $_{\mathbf{A}}$ \\
\hline Minimum & 0.05 & 0.01 & 0.7 \\
Median & 0.2 & 0.1 & 6 \\
Mean & 0.3 & 0.3 & 19 \\
S.D & 0.4 & 0.3 & 24 \\
S.E.M & 0.1 & 0.07 & 6 \\
Maximum & 2 & 1 & 74 \\
\hline
\end{tabular}

\subsection{Risk Characterization}

\subsubsection{Cumulative Probability Distribution (CPD) of Acute and Chronic Exposure Doses of Chlorpyrifos}

Generally, exposures to chlorpyrifos occur from background sources (e.g. food, water and air) in the environment, as well as from occupational application. Evaluation of chronic health risk due to chlorpyrifos exposure in this study was based on chronic exposure under three scenarios. These were:

(1) Lifetime Average Daily Dose of chlorpyrifos from background exposure (LADD $)_{B}$;

(2) Lifetime Average Daily Dose of chlorpyrifos from application exposure (LADDA); and

(3) Total Lifetime Average Daily Dose of chlorpyrifos from both background and application exposures $\left(\mathrm{LADD}_{\mathrm{T}}\right)$ (i.e. $\left.\mathrm{LADD}_{\mathrm{T}}=\mathrm{LADD}_{\mathrm{B}}+\mathrm{LADD}_{\mathrm{A}}\right)$.

For acute health risks, the evaluation was based on acute exposure under two scenarios. These were:

(1) Absorbed Daily Dose of chlorpyrifos from application exposure ( $\left.\operatorname{ADD}_{\mathrm{A}}\right)$; and 
(2) Total Absorbed Daily Dose of chlorpyrifos from both background and application exposures $\left(\mathrm{ADD}_{\mathrm{T}}\right)$ (i.e. $\left.\mathrm{ADD}_{\mathrm{T}}=\mathrm{LADD}_{\mathrm{B}}+\mathrm{ADD}_{\mathrm{A}}\right)$.

The CPD plots of $\mathrm{LADD}_{\mathrm{B}}, \mathrm{LADD}_{\mathrm{A}}$, and $\mathrm{LADD}_{\mathrm{T}}$ obtained with the data from Table 4 are presented in Figure 4. The exposure dose at the $50^{\text {th }}$ percentile $\left(\mathrm{CP}_{50}\right)$ and the $95^{\text {th }}$ percentile $\left(\mathrm{CP}_{95}\right)$ describes the levels of exposure among the median exposed and the 5\% highly-exposed groups, respectively. The dose at $\mathrm{CP}_{50}$ for $\mathrm{LADD}_{\mathrm{B}}, \mathrm{LADD}_{\mathrm{A}}$ and $\mathrm{LADD}_{\mathrm{T}}$ were $0.2 \mu \mathrm{g} / \mathrm{kg} / \mathrm{day}, 0.1 \mu \mathrm{g} / \mathrm{kg} / \mathrm{day}$ and 0.4 $\mu \mathrm{g} / \mathrm{kg} /$ day, respectively. At $\mathrm{CP}_{95}$, the dose was $2 \mu \mathrm{g} / \mathrm{kg} /$ day, $1 \mu \mathrm{g} / \mathrm{kg} /$ day and $3 \mu \mathrm{g} / \mathrm{kg} / \mathrm{day}$ for $\mathrm{LADD}_{\mathrm{B}}, \mathrm{LADD}_{\mathrm{A}}$ and $\mathrm{LADD}_{\mathrm{T}}$, respectively.

The CPD plots of $\mathrm{ADD}_{\mathrm{A}}$ and $\mathrm{ADD}_{\mathrm{T}}$ are presented in Figures $5 \mathrm{~A}$ and $5 \mathrm{~B}$, receptively. The dose at $\mathrm{CP}_{50}$ for both $\mathrm{ADD}_{\mathrm{A}}$ and $\mathrm{ADD}_{\mathrm{T}}$ were the same $(8 \mu \mathrm{g} / \mathrm{kg} /$ day $)$, whereas, the dose at $\mathrm{CP}_{95}$ for the two exposure scenarios were different at $83 \mu \mathrm{g} / \mathrm{kg} /$ day and $74 \mu \mathrm{g} / \mathrm{kg} /$ day, respectively. 


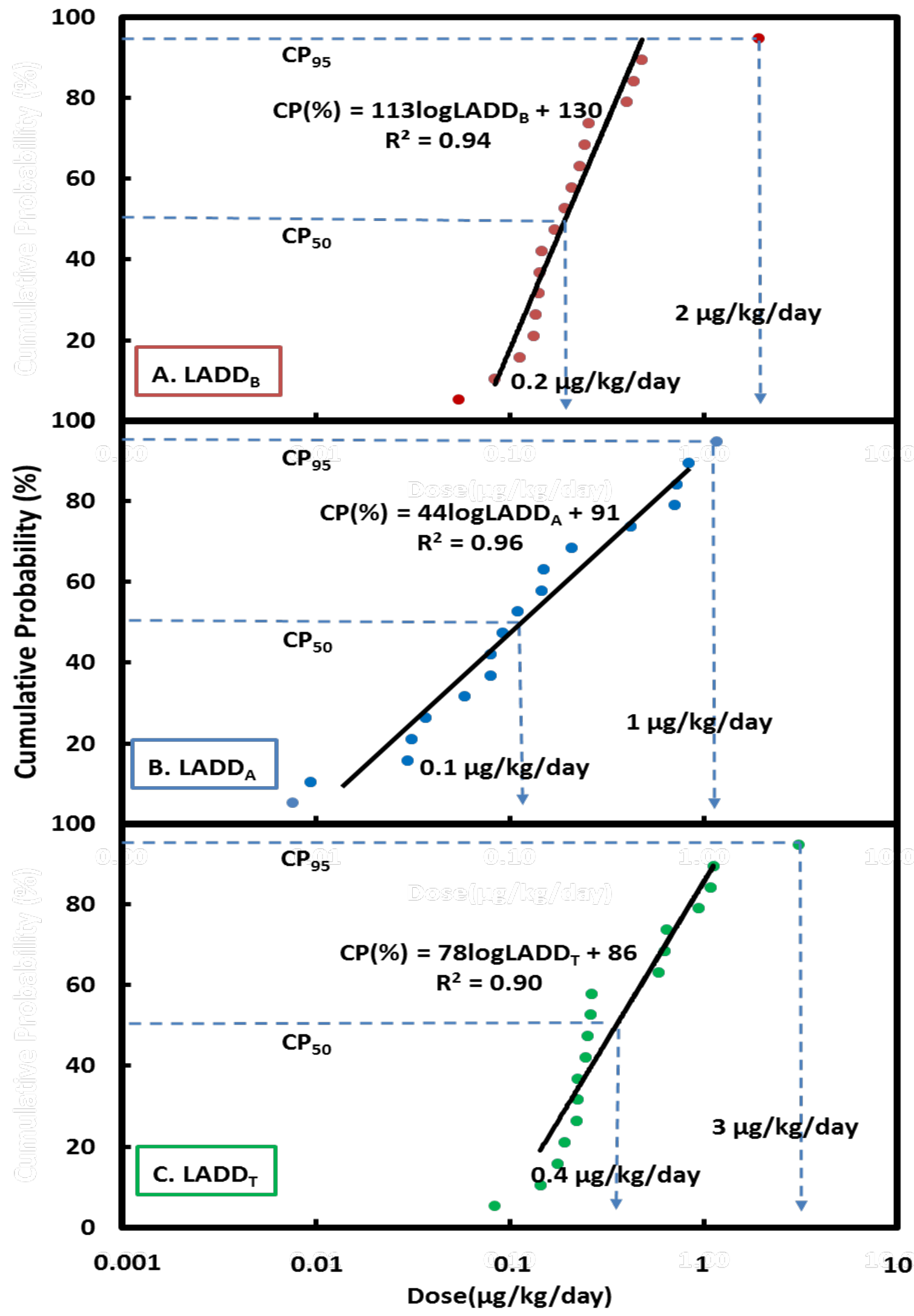

Fig. 4 Cumulative Probability Distribution (CPD) Plots of Chlorpyrifos Chronic Exposure Levels $\left(\mathrm{LADD}_{\mathrm{B}}, \mathrm{LADD}_{\mathrm{A}}\right.$ and $\left.\mathrm{LADD}_{\mathrm{T}}\right)$ among Applicators on Rice Farms in Ghana $(\mathrm{n}=18)$ 


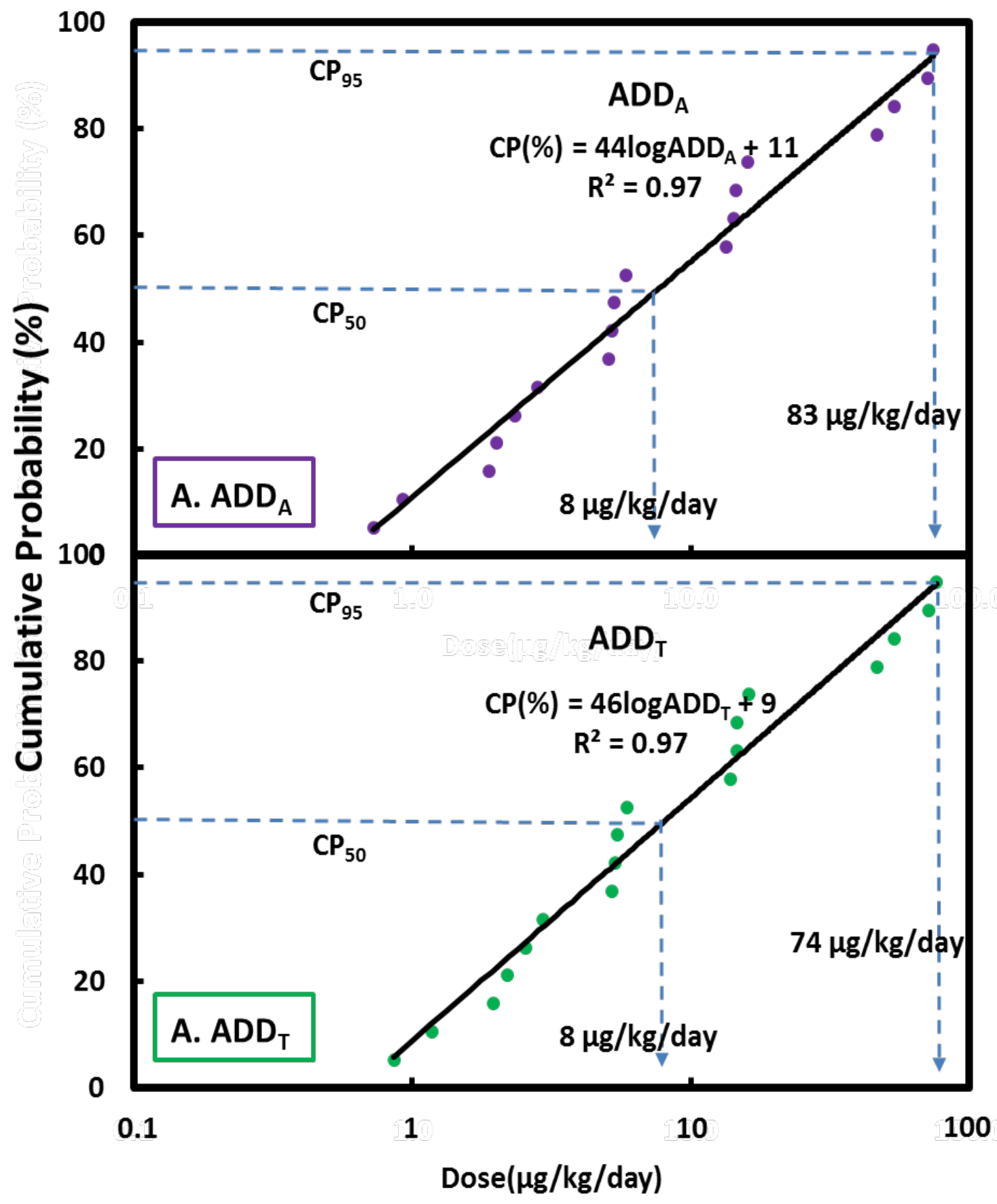

Fig. 5 Cumulative Probability Distribution Plot of Chlorpyrifos Acute Exposure Levels $\left(\mathrm{ADD}_{\mathrm{A}}\right.$ and $\left.\mathrm{ADD}_{\mathrm{T}}\right)$ among Applicators on Rice Farms in Ghana $(\mathrm{n}=18)$ 


\subsubsection{Hazard Quotients for Acute and Chronic Exposure to Chlorpyrifos}

The HQ values obtained for acute and chronic exposure to chlorpyrifos among the applicators are presented in Table 4. Using the acute exposure guideline value of the WHO, $\mathrm{HQ}_{50}$ value of 0.08 was obtained for both $\mathrm{ADD}_{\mathrm{A}}$ and $\mathrm{ADD}_{\mathrm{T}}$, whereas $\mathrm{HQ}_{95}$ values of 0.8 and 0.7 were obtained for $\mathrm{ADD}_{\mathrm{A}}$ and $\mathrm{ADD}_{\mathrm{T}}$, respectively. However, with the acute guideline value of the USEPA, $\mathrm{HQ}_{50}$ value of 1.6 was obtained for both $\mathrm{ADD}_{\mathrm{A}}$ and $\mathrm{ADD}_{\mathrm{T}}$, whereas $\mathrm{HQ}_{95}$ values of 16.6 and 14.7 were obtained for $\mathrm{ADD}_{\mathrm{A}}$ and $\mathrm{ADD}_{\mathrm{T}}$, respectively.

Applying the chronic guideline value of the WHO, $\mathrm{HQ}_{50}$ values of $0.02,0.01$, and 0.04 were obtained for $\mathrm{LADD}_{\mathrm{B}}, \mathrm{LADD}_{\mathrm{A}}$ and $\mathrm{LADD}_{\mathrm{T}}$, respectively. With $\mathrm{HQ}_{95}$, values of $0.2,0.2$, and 0.3 were obtained for $\mathrm{LADD}_{\mathrm{B}}, \mathrm{LADD}_{\mathrm{A}}$ and $\mathrm{LADD}_{\mathrm{T}}$, respectively. Using the chronic guideline value of the USEPA, HQ 50 values of $0.7,0.4$ and 1.2 were obtained for $\mathrm{LADD}_{\mathrm{B}}, \mathrm{LADD}_{\mathrm{A}}$ and $\mathrm{LADD}_{\mathrm{T}}$, respectively. With $\mathrm{HQ}_{95}$, values of 6.5 , 4, and 10.4 were obtained for $\mathrm{LADD}_{\mathrm{B}}, \mathrm{LADD}_{\mathrm{A}}$ and $\mathrm{LADD}_{\mathrm{T}}$, respectively. 
Table 4: Hazard Quotient Values of Chlorpyrifos Exposure Levels at $\mathrm{CP}_{50}$ and $\mathrm{CP}_{95}$ with Rice Farmers in Ghana $(\mathrm{n}=18)$

\begin{tabular}{|c|c|c|c|c|c|c|}
\hline \multirow{2}{*}{\multicolumn{3}{|c|}{ Exposure Dose ( $\mu \mathrm{g} / \mathrm{kg} / \mathrm{day})$}} & \multicolumn{4}{|c|}{ Hazard Quotient Value } \\
\hline & & & \multicolumn{2}{|c|}{ WHO Guideline } & \multicolumn{2}{|c|}{ USEPA Guideline } \\
\hline Acute Scenario & $\mathrm{CP}_{50}$ & $\mathrm{CP}_{95}$ & HQ50 & HQ95 & HQ50 & HQ95 \\
\hline $\mathrm{ADD}_{\mathrm{A}}$ & 8 & 83 & 0.08 & 0.8 & 1.6 & 16.6 \\
\hline $\mathrm{ADD}_{\mathrm{T}}$ & 8 & 74 & 0.08 & 0.7 & 1.6 & 14.7 \\
\hline Chronic Scenario & $\mathbf{C P}_{50}$ & $\mathrm{CP}_{95}$ & HQ50 & $\mathrm{HQ}_{95}$ & HQ50 & HQ $_{95}$ \\
\hline $\mathrm{LADD}_{\mathrm{B}}$ & 0.2 & 2 & 0.02 & 0.2 & 0.7 & 6.5 \\
\hline $\mathrm{LADD}_{\mathrm{A}}$ & 0.1 & 1 & 0.01 & 0.1 & 0.4 & 4.0 \\
\hline $\mathrm{LADD}_{\mathrm{T}}$ & 0.4 & 3 & 0.04 & 0.3 & 1.2 & 10.4 \\
\hline
\end{tabular}

(HQ values $>1$ have been bolded)

\subsection{Factors Associated with Absorbed Daily Dose of Chlorpyrifos from Application Exposure $\left(A D D_{A}\right)$}

The relationships between field factors and Absorbed Daily Dose from application exposure $\left(\mathrm{ADD}_{\mathrm{A}}\right)$ were statistically evaluated. The results of the Spearman $\rho$ correlation and Mann-Whitney U tests are presented in Tables 5 and 6, respectively. Table 6 shows that the quantities of insecticide formulation applied were statistically related to the $\mathrm{ADD}_{\mathrm{A}}$ levels. Increases in insecticide quantity significantly correlated with increases in $\mathrm{ADD}_{\mathrm{A}}(\mathrm{r}=0.59, \mathrm{p}<0.05)$. Application duration was also positively associated with $\mathrm{ADD}_{\mathrm{A}}$ levels $(\mathrm{r}=0.59, \mathrm{p}<0.05)$. The number of spray tanks applied by the applicators was also positively correlated with the levels of $\operatorname{ADD}_{\mathrm{A}}(\mathrm{r}=0.53, \mathrm{p}<0.05)$. In addition, the educational level of the applicators was positively associated with ADDA levels ( $p<$ 0.05). However, farm size, crop height, type of shirt, type of trousers, incidence of leakage, and incidence of spillage, were not statistically associated with the $\mathrm{ADD}_{\mathrm{A}}$ levels $(\mathrm{p}>0.05)$. 
Table 5: Spearman $\rho$ Correlation Coefficient $(r)$ Between $\mathrm{ADD}_{\mathrm{A}}$ Levels and Independent Continuous Variables (18).

\begin{tabular}{|c|c|c|c|c|c|c|}
\hline Variable & $\underset{(\mu \mathrm{g} / \mathrm{kg} / \mathrm{day})}{\mathrm{ADD}_{\mathrm{A}}}$ & $\begin{array}{l}\text { Insecticide } \\
\text { Formulation } \\
\text { Quantity } \\
\text { (mL) }\end{array}$ & $\begin{array}{l}\text { Applicat } \\
\text { ion } \\
\text { Duratio } \\
\text { n (min) }\end{array}$ & $\begin{array}{l}\text { Farm } \\
\text { Size } \\
\text { (ha) }\end{array}$ & $\begin{array}{l}\text { Crop } \\
\text { Height } \\
(\mathrm{cm})\end{array}$ & $\begin{array}{l}\text { No. of } \\
\text { Spray } \\
\text { Tank } \\
\text { S }\end{array}$ \\
\hline $\mathrm{ADD}_{\mathrm{A}}(\mu \mathrm{g} / \mathrm{kg} / \mathrm{day})$ & 1 & & & & & \\
\hline $\begin{array}{l}\text { Insecticide Formulation } \\
\text { Quantity (mL) }\end{array}$ & $0.59 *$ & 1 & & & & \\
\hline $\begin{array}{l}\text { Application Duration } \\
\text { (min) }\end{array}$ & $0.59 *$ & $0.87 * *$ & 1 & & & \\
\hline Farm Size (ha) & 0.19 & $0.76 * *$ & $0.65 * *$ & 1 & & \\
\hline Crop Height (cm) & 0.27 & 0.15 & $0.47 *$ & 0.26 & 1 & \\
\hline No. of Spray Tanks & $0.53 *$ & $0.99 * *$ & $0.87 * *$ & $0.76 * *$ & 0.15 & 1 \\
\hline
\end{tabular}

* Correlation is significant at the 0.05 level.

** Correlation is significant at the 0.01 level.

Table 6: Mann-Whitney U Test of Difference in $\mathrm{ADD}_{\mathrm{A}}(\mu \mathrm{g} / \mathrm{kg} /$ day) Levels Between Groups for Categorical Variables $(n=18)$.

\begin{tabular}{|c|c|c|c|c|}
\hline Variable & $\mathbf{n}$ & $\begin{array}{l}\text { Mean } \\
\text { Rank }\end{array}$ & $\mathbf{U}$ & p-value (2- tailed) \\
\hline $\begin{array}{c}\text { Type of Shirt } \\
\text { Short sleeve } \\
\text { Long sleeve } \\
\end{array}$ & $\begin{array}{c}8 \\
10 \\
\end{array}$ & $\begin{array}{c}10 \\
9 \\
\end{array}$ & 36 & 0.72 \\
\hline $\begin{array}{l}\text { Type of Trousers } \\
\text { Short trousers } \\
\text { Long trousers } \\
\end{array}$ & $\begin{array}{c}1 \\
17 \\
\end{array}$ & $\begin{array}{l}9.4 \\
12 \\
\end{array}$ & 6 & 0.63 \\
\hline $\begin{array}{l}\text { Incidence of Leaky Tank } \\
\text { Yes } \\
\text { No }\end{array}$ & $\begin{array}{l}9 \\
9 \\
\end{array}$ & $\begin{array}{c}10.3 \\
8.7 \\
\end{array}$ & 33 & 0.51 \\
\hline $\begin{array}{l}\text { Incidence of Spillage } \\
\text { Yes } \\
\text { No }\end{array}$ & $\begin{array}{c}15 \\
3\end{array}$ & $\begin{array}{c}8.8 \\
13\end{array}$ & 12 & 0.21 \\
\hline $\begin{array}{l}\text { Educational Level } \\
\text { Up to Junior High School } \\
\text { Above Junior High School }\end{array}$ & $\begin{array}{c}11 \\
7\end{array}$ & $\begin{array}{l}12.8 \\
5.29 \\
\end{array}$ & 9 & 0.008 \\
\hline
\end{tabular}




\subsection{Discussion}

\subsection{Elimination Half-life of Chlorpyrifos Found with the Applicators}

The half-life of chlorpyrifos (50 hours) determined in the present study is higher than those reported in previous studies, which ranges from 27 to 43 hours (Griffin et al. 1999; Meuling et al. 2005; Nolan et al. 1984; Wang et al. 2016; Williams et al. 2004). The longer half-life found in the present study could be attributable to the octanol/water partition coefficient of the compound. With an octanol/water partition coefficient (log $\left.\mathrm{K}_{\mathrm{OW}}\right)$ of 5.0 at $25^{\circ} \mathrm{C}(\mathrm{WHO}, 2009)$, chlorpyrifos would generally exhibit lipophilic properties and therefore has the potential to accumulate in the lipidrich stratum corneum of applicators (Griffin et al. 2000; Meuling et al. 2005; Moore et al. 2014).

With a half-life of 50 hours in the body, the level of post-application chlorpyrifos with the applicators would be expected to return to background levels in about 10 days after exposure (i.e. 5 half-lives). These findings have important implications for the design of biomonitoring programs to evaluate chlorpyrifos levels among applicators. Exposure to chlorpyrifos has often been evaluated based on urinary TCP levels obtained from the start of application up to 120 hours (5 days) post-application or less (34 hours) (Alexander et al. 2006; Griffin et al. 1999; Meuling et

al. 2005; Nolan et al. 1984; Phung et al. 2012b; Rodriguez et al. 2006; Williams et al. 2004). The measurements obtained within these sampling periods would likely under-estimate the levels of chlorpyrifos exposure, since its elimination would still be ongoing beyond these time periods. The findings of the present study also imply that, to accurately measure background exposure levels of chlorpyrifos, applicators should not apply the insecticide for at least 10 days prior to urine samples being taken. 


\subsection{Lifetime Average Daily Dose of Chlorpyrifos from Background Exposure $\left(L_{A D D}\right)$ Found with the Applicators}

Figure 6 shows the $\mathrm{LADD}_{\mathrm{B}}$ levels of chlorpyrifos among applicators from various countries. The median level of $\mathrm{LADD}_{\mathrm{B}}$ of this study $(0.2 \mu \mathrm{g} / \mathrm{kg} /$ day $)$ is similar to those found among applicators in Vietnam (0.1 $\mu \mathrm{g} / \mathrm{kg} /$ day) (Phung et al. 2012a) Sri-Lanka ( $0.2 \mu \mathrm{g} / \mathrm{kg} /$ day) (Aponso 2002), Nicaragua (0.2 $\mu \mathrm{g} / \mathrm{kg} /$ day) (Dowling et al. 2005), USA (0.2 $\mu \mathrm{g} / \mathrm{kg} /$ day) (Alexander et al. 2006) and Thailand (0.1 $\mu \mathrm{g} / \mathrm{kg} / \mathrm{day})$ (Panuwet et al. 2008). This finding possibly reflects comparable dietary exposure levels and household chlorpyrifos use practices among the applicators from these different countries. Background pesticide exposure levels within the population of a country can also be expected to be similar due to common exposure pathways. However, Bakke et al. (2009) have suggested that farmers could have additional sources of exposure. In that study, farmers had significantly elevated background levels of 2,4-D during all seasons, compared to non-farmers (2 $\mu \mathrm{g} 2,4-\mathrm{D} / \mathrm{g}$ creatinine and $0.2 \mu \mathrm{g} 2,4-\mathrm{D} / \mathrm{g}$ creatinine, respectively; $\mathrm{p}<0.05)$. Additional background exposure with farmers, may occur through storage of unused pesticides in household premises, household use of empty pesticide containers and washing of pesticide-contaminated farm clothing. 


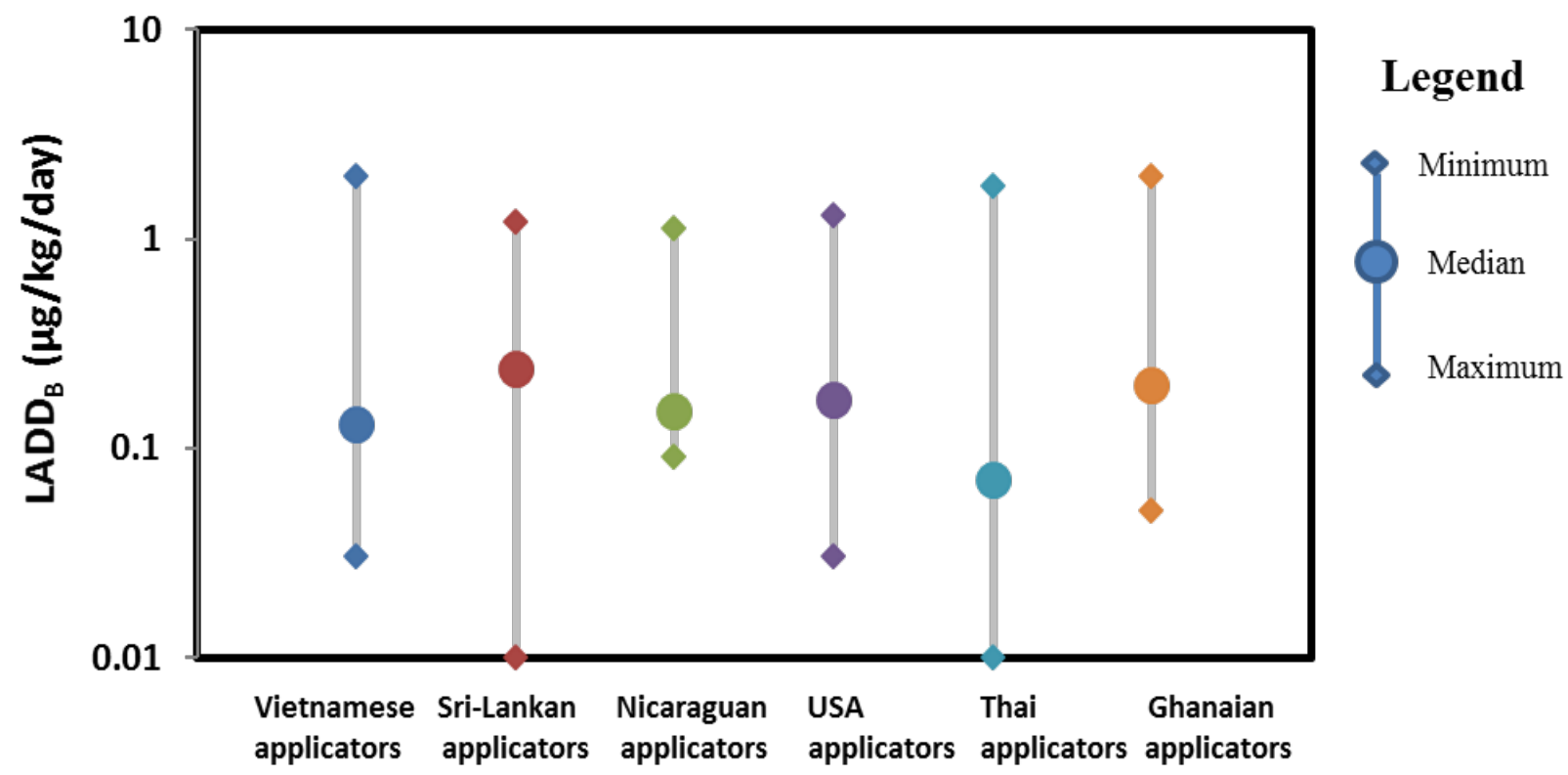

Fig. 6 Chlorpyrifos Exposure Levels from Background Sources (LADD ${ }_{B}$ ) among Applicators from Various Countries, adapted from Phung et al. (2012a) and Phung et al. (2012b)

\subsection{Absorbed Daily Dose of Chlorpyrifos from Application Exposure $\left(A D D_{A}\right)$ Found with the Applicators}

Figure 7 presents the levels of chlorpyrifos exposure from application among applicators in different countries. The median $\mathrm{ADD}_{\mathrm{A}}(6 \mu \mathrm{g} / \mathrm{kg} /$ day $)$ of this study is generally comparable to the levels found with applicators from other developing countries such as Vietnam $(8 \mu \mathrm{g} / \mathrm{kg} / \mathrm{day})$ (Phung et al. 2012b), Sri-Lanka (5 $\mu \mathrm{g} / \mathrm{kg} /$ day) (Aponso 2002) and Nicaragua $(9 \mu \mathrm{g} / \mathrm{kg} / \mathrm{day}$ ) (Dowling et al. 2005). Conversely, the median $\mathrm{ADD}_{\mathrm{A}}$ level of the present study is 22-folds less than that (134 $\mu \mathrm{g} / \mathrm{kg} / \mathrm{day})$ found with applicators in Egypt (Farahat et al. 2010). This is not unexpected because the levels found in the present study were for one spray event, compared to 16 consecutive days of spray events in the case of the Egyptian applicators. The median ADD $_{\mathrm{A}}$ level of the present study was 2.4 -folds higher than that $(2.5 \mu \mathrm{g} / \mathrm{kg} /$ day $)$ found with applicators from the USA (Alexander et al. 2006), although the areas (0.6 to 2.5 acres) treated by the applicators of the present study were far less than those (5 to 318 acres) treated by the applicators from USA. These differences are probably due to differences in pesticide handling practices 
among applicators in the present study and the applicators in USA. For instance, whereas none of the applicators in the present study used hand gloves, close to $60 \%$ of the applicators from USA used hand gloves. Moreover, the application in USA usually involved the applicators operating from an enclosed cab on a tractor. They would thus have had much lower risk of exposure compared to the applicators in the present study who used back packs with hand-held spraying lance.

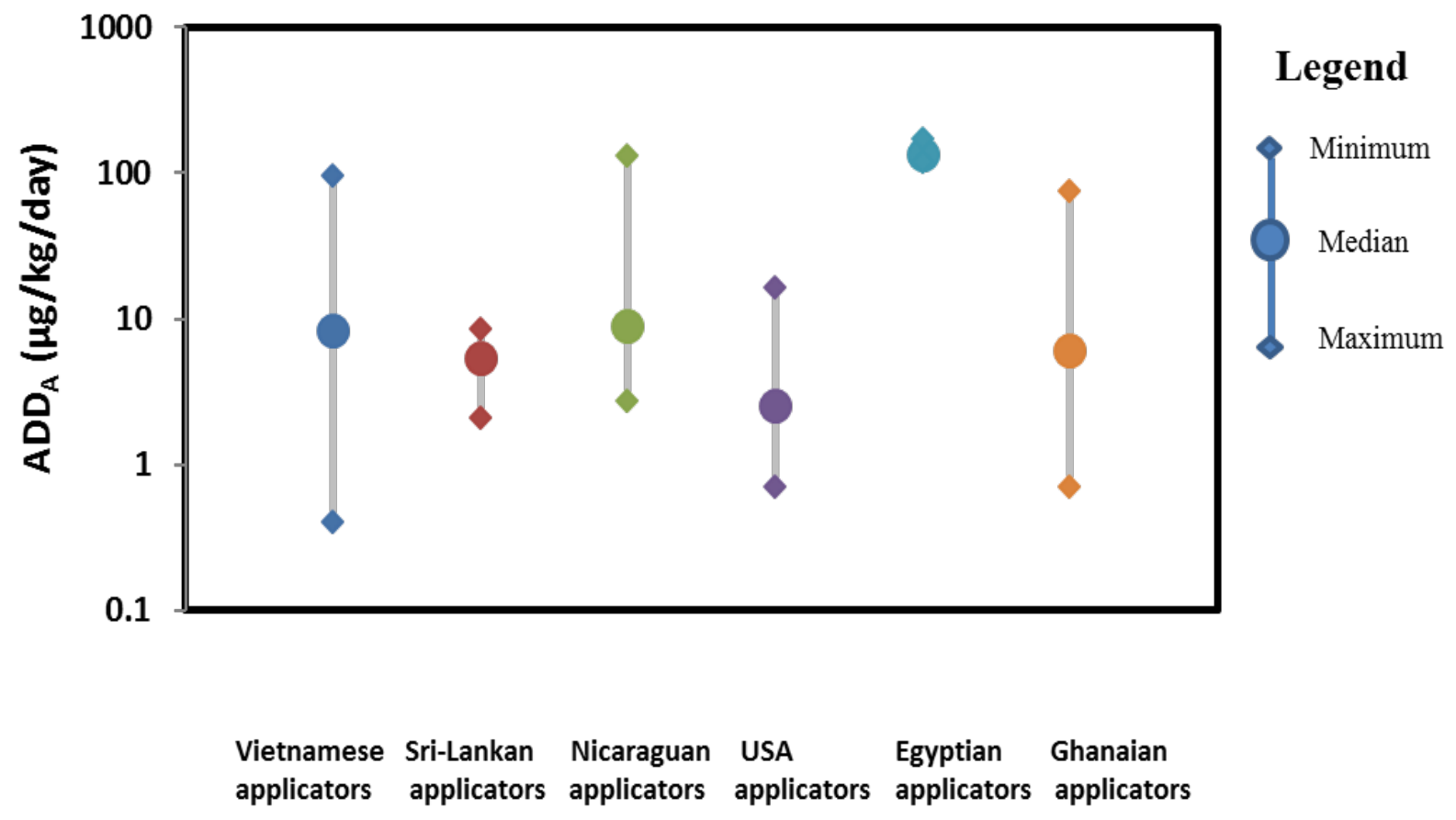

Fig. 7 Chlorpyrifos Exposure Levels from Application $\left(\mathrm{ADD}_{\mathrm{A}}\right)$ among Applicators in Various Countries, adapted from Phung et al. (2012a)

\subsection{Life-time Absorbed Daily Dose of Chlorpyrifos from Application Exposure $\left(L_{A D D}\right)$ Found with the Applicators}

The study by Phung et al. (2013) is the only investigation from the scientific literature that has evaluated chronic exposure to chlorpyrifos among agricultural applicators. The median LADD $_{\mathrm{A}}$ $(0.1 \mu \mathrm{g} / \mathrm{kg} /$ day $)$ in the present study is slightly lower than that $(0.31 \mu \mathrm{g} / \mathrm{kg} / \mathrm{day})$ found with 
applicators on rice farms in Vietnam (Phung et al. 2013). This difference could be explained by differences in exposure frequencies between the two applicator groups. The applicators in the present study apply chlorpyrifos about 6 times in a year $(3$ applications per crop season $\times 2$ crop seasons in a year), whereas the Vietnamese applicators apply chlorpyrifos 10 times in a year (Phung 2012).

\subsection{Risk of Adverse Effects from Acute and Chronic Exposure to Chlorpyrifos among the Applicators}

The $\mathrm{HQ}_{50}(0.08)$ and $\mathrm{HQ}_{95}(0.7$ and 0.8$)$ values obtained with the guideline values of the WHO were less than unity. These suggested that there was no risk of adverse health effects among both the median-exposed and 5\% highly-exposed applicator groups, with all the acute and chronic exposure scenarios. However, the $\mathrm{HQ}_{50}$ (1.6) and $\mathrm{HQ}_{95}$ (14.7 and 16.6) values calculated with the acute guideline value of the USEPA were more than unity. These suggested that both the median and the 5\% highly-exposed groups were at high risk of acute health effects when acute occupational exposure were considered separately $\left(\mathrm{ADD}_{\mathrm{A}}\right)$, as well as in combination with background exposure $\left(\mathrm{ADD}_{\mathrm{T}}\right)$. Although, the USEPA chronic exposure guideline value suggested no risk of adverse health effects among the median-exposed group, when background exposure $\left(\mathrm{HQ}_{50}, 0.7\right)$ and chronic occupational application $\left(\mathrm{HQ}_{50}, 0.4\right)$ were considered separately, there was risk when the two exposures were considered together $\left(\mathrm{HQ}_{50}, 1.2\right)$. Among the 5\% highly-exposed group, the HQ95 values $(4,6.5$ and 10.4) obtained with the chronic exposure guideline value of the USEPA suggested that background exposure and occupational exposure to chlorpyrifos posed high risk of chronic adverse health effects, when considered separately as well as together. 
The differences in chlorpyrifos guideline values set by the WHO, USEPA and other regulatory bodies can complicate health risk characterization, as observed in this study. An evaluation carried out by Phung et al. (2015), based on previous human epidemiological studies, shows that adverse health effects may occur at acute chlorpyrifos exposure levels ( 0.5 to $35.7 \mu \mathrm{g} / \mathrm{kg} /$ day $)$ far below the acute exposure guideline value of the WHO $(100 \mu \mathrm{g} / \mathrm{kg} /$ day $)$. Such acute adverse effects may include cholinesterase inhibition, subclinical neuropathy, sensory and motor defects. Similarly, the study suggested that adverse health effects may result at chronic exposure levels of 0.3 to 6.7 $\mu \mathrm{g} / \mathrm{kg} / \mathrm{day}$, which are much lower than the chronic exposure guideline value of the WHO (10 $\mu \mathrm{g} / \mathrm{kg} /$ day). Some of the possible chronic adverse effects include reproductive, developmental and endocrine defects. In contrast, the acute and chronic exposure guideline values set by the USEPA are at or below exposure doses indicated in the study by Phung et al. (2015). It can therefore be argued that the USEPA's guideline values are not artificially low, but are more protective of public health. Thus, the risk characterisation results of the present study, based on the USEPA guideline values, can be considered more accurate.

\subsection{Factors Associated with Absorbed Daily Dose of Chlorpyrifos from Application Exposure $\left(A D D_{A}\right)$}

The quantity of insecticide formulation applied was found to be positively associated with the $\mathrm{ADD}_{\mathrm{A}}$ levels $(\mathrm{r}=0.59, \mathrm{p}<0.05)$. Similarly, Phung et al. (2012a) found among rice farmers that, the quantities of chlorpyrifos applied significantly influenced the levels of $\mathrm{ADD}_{\mathrm{A}}(\mathrm{r}=0.69, \mathrm{p}<$ 0.05). A stepwise multiple linear regression analysis in that study showed that, $\mathrm{ADD}_{\mathrm{A}}$ increased by $0.48 \mu \mathrm{g} / \mathrm{kg} /$ day per gram increase of chlorpyrifos applied. Likewise, Bakke et al. (2009) found among corn farmers that the quantity $(\mathrm{kg})$ of pesticide applied was a predictor $(\beta=0.008, \mathrm{p}<0.05)$

of atrazine exposure, measured as urinary atrazine mercapturate (AZM). In a related study based 
on previous studies and expert judgement, Marquart et al. (2003) also reported that the quantity of pesticide applied influences the levels of dermal exposure.

Application duration was also positively associated with $\mathrm{ADD}_{\mathrm{A}}$ levels $(\mathrm{r}=0.59, \mathrm{p}<0.05)$. Phung et al. (2012a) likewise found that the number of hours spent applying insecticides was positively associated with the level of exposure $(r=0.69)$. Also, Hines and Deddens (2001) demonstrated that spray duration was a significant determinant of urinary TCP levels and chlorpyrifos concentration in the ambient air among termiticide applicators $(\beta=0.002, p<0.001$ and $\beta=0.006$, $\mathrm{p}<0.001$, respectively). A possible explanation for the findings of the present study is that, extended application duration normally allows more time for pesticide residues deposited on the skin to be absorbed, particularly for pesticides such as chlorpyrifos that exhibit lipophilic properties (Griffin et al. 2000; Meuling et al. 2005). In evaluating dermal absorption and distribution of organophosphate insecticides with in-vitro human skin model, Moore et al. (2014) found that there was an increased skin reservoir because of extended exposure duration. This increased reservoir would be available for later systemic absorption.

Another field factor that positively correlated with the levels of $\mathrm{ADD}_{\mathrm{A}}$ was the number of spray tanks applied by the applicators $(\mathrm{r}=0.53, \mathrm{p}>0.05)$. Some research has shown that hand contamination can be the highest contributor to total exposure among pesticide applicators (Atabila et al. 2017; Baldi et al. 2006; Machera 2003; Vitali et al. 2009), with the most hand contamination occurring during mixing and loading of pesticides into spray tanks (Gao et al. 2014; Kim et al. 2014). None of the applicators in the present study used hand gloves, a situation that predisposed them to direct hand contamination. Alexander et al. (2006) similarly found among licensed applicators who applied liquid chlorpyrifos with boom sprayers that, urinary TCP levels 
significantly increased with increase in the number of spray loads applied. The mean urinary TCP levels found among applicators who used 1 to 2, 3 to 5, and more than 5 spray loads were 24, 29 and $76 \mu \mathrm{g}$ TCP/ L urine, respectively $(\mathrm{p}<0.05)$.

In addition, the educational level of the applicators was found to influence the $\mathrm{ADD}_{\mathrm{A}}$ levels. Applicators with educational levels up to Junior High School had higher $\mathrm{ADD}_{\mathrm{A}}$ levels (mean rank of 12.8) compared to those with educational levels above Junior High School (mean rank of 5.29). Similar findings have been reported by Phung et al. (2012a). Generally, highly educated applicators are more likely to access, read and understand information on pesticide health risks and exposure minimization strategies. They are therefore more likely to handle pesticides safely, compared to applicators with minimal educational level (Jallow et al. 2017).

Some of the independent variables were found to be significantly associated with one another. Insecticide quantity positively correlated with spraying duration, farm size and the number of spray tanks applied $(p>0.01)$. Spray duration was also positively related with farm size, crop height and the number of spray tanks applied $(p>0.05)$. Moreover, the number of spray tanks applied was positively associated with farm size $(p>0.01)$. Consequently, some of the identified associations between $\mathrm{ADD}_{\mathrm{A}}$ levels and the independent variables in this study can be secondary and may require multiple linear regression analysis to identify the primary associations. However, such analysis was not carried out, owing to the small sample size of the study. Generally, a minimum of 50 observations is required for multiple linear regression analysis (Van Voorhis and Morgan 2007). 
In contrast to the above-mentioned field factors, farm size, crop height, type of shirt, type of trousers, incidence of leakage, and incidence of spillage, did not statistically influence the $\mathrm{ADD}_{\mathrm{A}}$ levels in this study $(p>0.05)$.

\subsection{Conclusions}

Prior to application, the median absorbed dose of chlorpyrifos (background exposure) with the applicators was $0.2 \mu \mathrm{g} / \mathrm{kg} /$ day (range, 0.05 to $2 \mu \mathrm{g} / \mathrm{kg} /$ day). Following application, the median absorbed dose of chlorpyrifos (application exposure) increased 30-fold to $6 \mu \mathrm{g} / \mathrm{kg} /$ day (range, 0.7 to $74 \mu \mathrm{g} / \mathrm{kg} /$ day). The mean elimination half-life $\left(\mathrm{t}_{1 / 2}\right)$ of chlorpyrifos was calculated to be 50 hours, which suggested that the levels of chlorpyrifos found with the applicators would be expected to return to background levels about 10 days after exposure (i.e. 5 half-lives).

The WHO guideline values suggested that there was no risk of chlorpyrifos adverse health effects among both the median-exposed and 5\% highly-exposed applicator groups, with all the acute and chronic exposure scenarios evaluated. However, the USEPA's guideline value suggested risk of acute adverse health effects among the median-exposed group (HQ $\mathrm{H}_{50} 1.6$ ) and the 5\% highlyexposed group ( $\mathrm{HQ}_{95}$ 16.6), due to exposure from occupational application ( $\left.\mathrm{ADD}_{\mathrm{A}}\right)$. Also, risks of acute adverse effects are suggested due to the combined exposure from background and occupational application $\left(\mathrm{ADD}_{\mathrm{T}}\right)$ among the median-exposed group ( $\left.\mathrm{HQ}_{50} 1.6\right)$ and the $5 \%$ highlyexposed group (HQ95 14.7). With chronic adverse effects, the USEPA's guideline value suggested risks among the median-exposed group from the combined chlorpyrifos exposure from background and occupational application $\left(\mathrm{LADD}_{\mathrm{T}}\right)$, as the HQ value exceeded unity $\left(\mathrm{HQ}_{50} 1.2\right)$. 
Also, there was risk of chronic health effects among the 5\% highly-exposed group, due to exposure from background ( $\left.\mathrm{LADD}_{\mathrm{B}}\right)\left(\mathrm{HQ}_{95} 6.5\right)$, occupational application $\left(\mathrm{LADD}_{\mathrm{A}}\right)\left(\mathrm{HQ}_{95} 4\right)$, as well as from the combined exposure from background and occupational application $\left(\mathrm{LADD}_{\mathrm{T}}\right)\left(\mathrm{HQ}_{95}\right.$ 10.4).

The quantity of chlorpyrifos formulation applied, application duration and the number of spray tanks applied, positively correlated with the levels of chlorpyrifos exposure from occupational application $(\mathrm{p}<0.05)$. Therefore, to reduce chlorpyrifos exposure and health risk among applicators, interventions may be targeted at reducing the quantity of insecticide applied, duration of application and the number of spray tanks applied. Also, the applicators may consider positioning the lance of spray device sideways in order not to walk into the sprayed areas to avoid excessive contamination.

\section{References}


Albertini R, Bird M, Doerrer N, Needham L, Robison S, Sheldon L, Zenick H (2006) The Use Of Biomonitoring Data In Exposure And Human Health Risk Assessments Environ Health Perspect 114:1755-1762 doi:10.1289/ehp.9056

Alexander BH, Burns CJ, Bartels MJ, Acquavella JF, Mandel JS, Gustin C, Baker BA (2006) Chlorpyrifos exposure in farm families: results from the farm family exposure study J Expo Sci Environ Epidemiol 16:447-456 doi:10.1038/sj.jes.7500475

Amoah P, Drechsel P, Abaidoo RC, Ntow WJ (2006) Pesticide and pathogen contamination of vegetables in Ghana's urban markets Arch Environ Contam Toxicol 50:1-6 doi:10.1007/s00244-004-0054-8

Aponso GLM (2002) Exposure and health risk assessment for farmers occupationally exposed to chlorpyrifos in Sri Lanka and drinking water and house dust analysis for chlorpyrifos. Thesis, Oregon State University

Atabila A, Phung DT, Hogarh JN, Osei-Fosu P, Sadler R, Connell D, Chu C (2017) Dermal exposure of applicators to chlorpyrifos on rice farms in Ghana Chemosphere 178:350-358 doi:http://dx.doi.org/10.1016/i.chemosphere.2017.03.062

Baker BA, Alexander BH, Mandel JS, Acquavella JF, Honeycutt R, Chapman P (2005) Farm Family Exposure Study: methods and recruitment practices for a biomonitoring study of pesticide exposure J Expo Anal Environ Epidemiol 15:491-499 doi:10.1038/sj.jea.7500427

Bakke B et al. (2009) Exposure to atrazine and selected non-persistent pesticides among corn farmers during a growing season J Expo Sci Environ Epidemiol 19:544-554 doi:10.1038/jes.2008.53

Baldi I, Lebailly P, Jean S, Rougetet L, Dulaurent S, Marquet P (2006) Pesticide contamination of workers in vineyards in France J Expo Sci Environ Epidemiol 16:115-124 doi:10.1038/sj.jea.7500443

Barr DB, Angerer J (2006) Potential uses of biomonitoring data: a case study using the organophosphorus pesticides chlorpyrifos and malathion Environ Health Perspect 114:17631769

Barr DB, Wilder LC, Caudill SP, Gonzalez AJ, Needham LL, Pirkle JL (2005) Urinary Creatinine Concentrations in the U.S. Population: Implications for Urinary Biologic Monitoring Measurements Environ Health Perspect 113:192-200 doi:10.1289/ehp.7337

Beal SL (2001) Ways to fit a PK model with some data below the quantification limit J Pharmacokinet Pharmacodyn 28:481-504

Cocker J, Mason HJ, Warren ND, Cotton RJ (2011) Creatinine adjustment of biological monitoring results Occup Med (Lond) 61:349-353 doi:10.1093/occmed/kqr084

Colombo A, Orsi F, Bonfanti P (2005) Exposure to the organophosphorus pesticide chlorpyrifos inhibits acetylcholinesterase activity and affects muscular integrity in Xenopus laevis larvae Chemosphere 61:1665-1671 doi:10.1016/j.chemosphere.2005.04.005

Costa LG (2006) Current issues in organophosphate toxicology Clin Chim Acta 366:1-13 doi:10.1016/j.cca.2005.10.008

Das GP, Jamil K, Rahman MF (2006) Effect of four organophosphorus compounds on human blood acetylcholinesterase: in vitro studies Toxicol Mech Methods 16:455-459 doi:10.1080/15376520600719281

Dowling KC, Blanco LE, Martinez I, Aragon A, Bernard CE, Krieger RI (2005) Urinary 3,5,6-trichloro-2pyridinol levels of chlorpyrifos in Nicaraguan applicators and small farm families Bull Environ Contam Toxicol 74:380-387

Eaton DL et al. (2008) Review of the toxicology of chlorpyrifos with an emphasis on human exposure and neurodevelopment Crit Rev Toxicol 38 Suppl 2:1-125 doi:10.1080/10408440802272158

Farahat FM et al. (2011) Biomarkers of chlorpyrifos exposure and effect in Egyptian cotton field workers Environ Health Perspect 119:801-806 doi:10.1289/ehp.1002873

Farahat FM et al. (2010) Chlorpyrifos exposures in Egyptian cotton field workers Neurotoxicology 31:297-304 doi:10.1016/j.neuro.2010.02.005

Fenske RA, Farahat FM, Galvin K, Fenske EK, Olson JR (2012) Contributions of inhalation and dermal exposure to chlorpyrifos dose in Egyptian cotton field workers Int J Occup Environ Health 18:198-209 doi:10.1179/1077352512z.00000000030 
Fosu-Mensah BY, Okoffo ED, Darko G, Gordon C (2016) Organophosphorus pesticide residues in soils and drinking water sources from cocoa producing areas in Ghana Environmental Systems Research 5:10 doi:10.1186/s40068-016-0063-4

Gao B et al. (2014) Measurement of operator exposure to chlorpyrifos Pest management science 70:636-641 doi:10.1002/ps.3601

Garabrant DH et al. (2009) Cholinesterase inhibition in chlorpyrifos workers: Characterization of biomarkers of exposure and response in relation to urinary TCPy J Expo Sci Environ Epidemiol 19:634-642 doi:10.1038/jes.2008.51

Gerken A, Suglo A, M B (2001) Crop Protection Policy in Ghana: An Economic and Institutional Analysis of Current Practice and Factors Influencing Pesticide Use. Institute of Horticultural Economics, Hannover, Germany

Griffin P, Mason H, Heywood K, Cocker J (1999) Oral and dermal absorption of chlorpyrifos: a human volunteer study Occup Environ Med 56:10-13

Griffin P, Payne M, Mason H, Freedlander E, Curran AD, Cocker J (2000) The in vitro percutaneous penetration of chlorpyrifos Hum Exp Toxicol 19:104-107

Grube A, Donaldson D, Kiely T, Wu L (2011) Pesticides industry sales and usage US EPA, Washington, DC

Health Canada (2014) Re-evaluation Decision for Propoxur. Health Canada Pest Management Regulatory Agency, Ottawa, Ontario

Hines CJ, Deddens JA (2001) Determinants of chlorpyrifos exposures and urinary 3,5,6-trichloro-2pyridinol levels among termiticide applicators Ann Occup Hyg 45:309-321

Jallow MFA, Awadh DG, Albaho MS, Devi VY, Thomas BM (2017) Pesticide Knowledge and Safety Practices among Farm Workers in Kuwait: Results of a Survey Int J Environ Res Public Health 14:340 doi:10.3390/ijerph14040340

John EM, Shaike JM (2015) Chlorpyrifos: pollution and remediation Environ Chem Lett 13:269-291 doi:10.1007/s10311-015-0513-7

Kim E, Lee J, Sung J, Lee J, Shin Y, Kim J (2014) Exposure and Risk Assessment for Operator Exposure to Insecticide Acetamiprid during Water Melon Cultivation in Greenhouse using Whole Body Dosimetry The Korean Journal of Pesticide Science 18:247-257 doi:10.7585/kjps.2014.18.4.247

Kolavalli S et al. (2012) Economic Transformation in Ghana: Where Will the Path Lead? International Food Policy Research Institute,

Lu C, Bravo R, Caltabiano LM, Irish RM, Weerasekera G, Barr DB (2005) The presence of dialkylphosphates in fresh fruit juices: implication for organophosphorus pesticide exposure and risk assessments J Toxicol Environ Health A 68:209-227 doi:10.1080/15287390590890554

Machera K (2003) Determination of potential dermal and inhalation operator exposure to malathion in greenhouses with the whole body dosimetry method Ann Occup Hyg 47:61-70 doi:10.1093/annhyg/mef097

Mandel JS, Alexander BH, Baker BA, Acquavella JF, Chapman P, Honeycutt R (2005) Biomonitoring for farm families in the Farm Family Exposure Study Scand J Work Environ Health 31:98-104

Marquart J, Brouwer DH, Gijsbers JH, Links IH, Warren N, van Hemmen JJ (2003) Determinants of dermal exposure relevant for exposure modelling in regulatory risk assessment Ann Occup Hyg 47:599607

Mattah MM, Mattah PAD, Futagbi G (2015) Pesticide Application among Farmers in the Catchment of Ashaiman Irrigation Scheme of Ghana: Health Implications J Environ Public Health 2015:7 doi:10.1155/2015/547272

Meuling WJ, Ravensberg LC, Roza L, van Hemmen JJ (2005) Dermal absorption of chlorpyrifos in human volunteers Int Arch Occup Environ Health 78:44-50 doi:10.1007/s00420-004-0558-6

MoFA - Ministry of Food and Agriculture (2011) Ghana Commercial Agriculture Project (GCAP) Pest Management Plan. Ministry of Food and Agriculture, Accra

Mohabbati-Kalejahi E, Azimirad V, Bahrami M, Ganbari A (2012) A review on creatinine measurement techniques Talanta 97:1-8 doi:10.1016/j.talanta.2012.04.005 
Moore CA, Wilkinson SC, Blain PG, Dunn M, Aust GA, Williams FM (2014) Percutaneous absorption and distribution of organophosphates (chlorpyrifos and dichlorvos) following dermal exposure and decontamination scenarios using in vitro human skin model Toxicol Lett 229:66-72 doi:10.1016/j.toxlet.2014.06.008

Nolan RJ, Rick DL, Freshour NL, Saunders JH (1984) Chlorpyrifos: pharmacokinetics in human volunteers Toxicol Appl Pharmacol 73:8-15

Okoffo ED, Mensah M, Fosu-Mensah BY (2016) Pesticides exposure and the use of personal protective equipment by cocoa farmers in Ghana Environmental Systems Research 5:17 doi:10.1186/s40068-016-0068-z

Panuwet P, Prapamontol T, Chantara S, Thavornyuthikarn P, Montesano MA, Whitehead RD, Jr., Barr DB (2008) Concentrations of urinary pesticide metabolites in small-scale farmers in Chiang Mai Province, Thailand Sci Total Environ 407:655-668 doi:10.1016/j.scitotenv.2008.08.044

Phung DT (2012) Assessing and Reducing Risk Due to Chlorpyrifos Use among Rice Farmers in Vietnam: From Probabilistic Risk Assessment to Safety Strategy Development. Thesis, Griffith University

Phung DT, Connell D, Chu C (2015) A new method for setting guidelines to protect human health from agricultural exposure by using chlorpyrifos as an example Ann Agric Environ Med 22:275-280 doi:10.5604/12321966.1152080

Phung DT, Connell D, Miller G, Chu C (2012a) Probabilistic assessment of chlorpyrifos exposure to rice farmers in Viet Nam J Expo Sci Environ Epidemiol 22:417-423 doi:10.1038/jes.2012.32

Phung DT et al. (2012b) Biological monitoring of chlorpyrifos exposure to rice farmers in Vietnam Chemosphere 87:294-300 doi:10.1016/j.chemosphere.2011.11.075

Phung DT, Connell D, Yu Q, Chu C (2013) Health risk characterization of chlorpyrifos using epidemiological dose-response data and probabilistic techniques: a case study with rice farmers in Vietnam Risk Anal 33:1596-1607 doi:10.1111/risa.12023

Rauh VA et al. (2012) Brain anomalies in children exposed prenatally to a common organophosphate pesticide Proc Natl Acad Sci U S A 109:7871-7876 doi:10.1073/pnas.1203396109

Rodriguez T, Younglove L, Lu C, Funez A, Weppner S, Barr DB, Fenske RA (2006) Biological monitoring of pesticide exposures among applicators and their children in Nicaragua Int J Occup Environ Health 12:312-320 doi:10.1179/oeh.2006.12.4.312

Ross J, Chester G, Driver J, Lunchick C, Holden L, Rosenheck L, Barnekow D (2008) Comparative evaluation of absorbed dose estimates derived from passive dosimetry measurements to those derived from biological monitoring: validation of exposure monitoring methodologies J Expo Sci Environ Epidemiol 18:211-230 doi:10.1038/sj.jes.7500591

Scher DP, Sawchuk RJ, Alexander BH, Adgate JL (2008) Estimating absorbed dose of pesticides in a field setting using biomonitoring data and pharmacokinetic models J Toxicol Environ Health A 71:373383 doi:10.1080/15287390701801638

Smegal DC (2000) Human health risk assessment Chlorpyrifos. U.S. Environmental Protection Agency, Washington $D C$

Solomon KR, Houghton D, Harris SA (2005) Nonagricultural and residential exposures to pesticides Scand J Work Environ Health:74-81

Toutain PL, Bousquet-Melou A (2004) Plasma terminal half-life J Vet Pharmacol Ther 27:427-439 doi:10.1111/j.1365-2885.2004.00600.x

USEPA - United States Environmental Protection Agency (2007) Dermal Exposure Assessment: A Summary of EPA Approaches. United States Environmental Protection Agency, Washington, DC

Van Voorhis CRW, Morgan BL (2007) Understanding Power and Rules of Thumb for Determining Sample Sizes Tutorials in Quantitative Methods for Psychology 3:43 - 50

Vitali M, Protano C, Del Monte A, Ensabella F, Guidotti M (2009) Operative modalities and exposure to pesticides during open field treatments among a group of agricultural subcontractors Arch Environ Contam Toxicol 57:193-202 doi:10.1007/s00244-008-9225-3 
Wang L, Liu Z, Zhang J, Wu Y, Sun H (2016) Chlorpyrifos exposure in farmers and urban adults: Metabolic characteristic, exposure estimation, and potential effect of oxidative damage Environ Res 149:164-170 doi:10.1016/j.envres.2016.05.011

WHO - World Health Organization (2015) Ghana: WHO Statistical Profile. World Health Organization, WHO (2009) WHO Specifications and Evaluations for Public Health Pesticides - Chlorpyrifos. World Health Organization, Geneva, Switzerland

Whyatt RM et al. (2004) Prenatal insecticide exposures and birth weight and length among an urban minority cohort Environ Health Perspect 112:1125-1132

Williams RL, Aston LS, Krieger RI (2004) Perspiration increased human pesticide absorption following surface contact during an indoor scripted activity program J Expo Anal Environ Epidemiol 14:129-136 doi:10.1038/sj.jea.7500301

Yang CC, Deng JF (2007) Intermediate syndrome following organophosphate insecticide poisoning J Chin Med Assoc 70:467-472 doi:10.1016/s1726-4901(08)70043-1 